\title{
KONSTRUKSI KECANTIKAN PEREMPUAN PADA NOVEL CANTIK ITU LUKA KARYA EKA KURNIAWAN
}

\author{
Fitri Wulandari ${ }^{1}$, David Setiadi ${ }^{2}$, Asep Firdaus ${ }^{3}$ \\ ${ }^{1}$ Universitas Muhammadiyah Sukabumi, fitriwulandari123@ummi.ac.id \\ ${ }^{2}$ Universitas Muhammadiyah Sukabumi, david156@ummi.ac.id \\ ${ }^{3}$ Universitas Muhammadiyah Sukabumi, asepfirdaus@ummi.ac.id
}

\begin{abstract}
Literature is a disclosure of life that comes from the environment, life is ecperienced, witnessed, heard and even read by the author, then conveyed by the author to the reader by using language as a medium to connect the two. This study aims to describe the construction of female beauty in the beautiful novel that is wound by Eka Kurniawan. In this study, using qualitative research methods with library techniques. The results of this study indicate that in the beautiful novel, there is a construction of female beauty in the figures of Dewi Ayu, Alamanda, Adinda, Maya Dewi, and Cantik with different perspectives in interpreting the beauty of the female character.
\end{abstract}

Keyword(s): feminist literary criticism, character and characterization, beauty construction

\begin{abstract}
ABSTRAK
Sastra merupakan sebuah pengungkapan kehidupan yang bersumber dari lingkungan, kehidupan yang dialami, disaksikan, didengar bahkan dibaca oleh pengarang, kemudian disampaikan oleh pengarang kepada pembaca dengan menggunakan bahasa sebagai media untuk menghubungkan keduanya. Penelitian ini bertujuan untuk mendeskripsik an konstruksi kecantikan perempuan pada novel Cantik Itu Luka karya Eka Kurniawan. Dalam penelitian ini, menggunakan metode penelitian kualitatif dengan teknik kepustakaan. Hasil penelitian ini menunjukkan bahwa dalam novel Cantik Itu Luka terdapat konstruksi kecantikan perempuan pada tokoh Dewi Ayu, Alamanda, Adinda, Maya Dewi, dan Cantik dengan sudut pandang yang berbeda dalam mengartikan kecantikan yang dimiliki tokoh perempuan tersebut.
\end{abstract}

Kata Kunci : kritik sastra feminis, tokoh dan penokohan, konstruksi kecantikan

How to Cite: Wulandari, F., Setiadi, D., \& Firdaus, A. (2021). KONSTRUKSI KECANTIKAN PEREMPUAN PADA NOVEL CANTIK ITU LUKA KARYA EKA KURNIAWAN. Bahtera Indonesia; Jurnal Penelitian Bahasa Dan Sastra Indonesia , 6(2), 276-291. https://doi.org/10.31943/bi.v6i2.135

DOI: https://doi.org/10.31943/bi.v6i2.135

\section{PENDAHULUAN}

Sastra merupakan sebuah pengungkapan kehidupan yang bersumber dari lingkungan, kehidupan yang dialami, disaksikan, didengar bahkan dibaca oleh pengarang, kemudian disampaikan oleh pengarang kepada pembaca dengan menggunakan bahasa sebagai media untuk menghubungkan keduanya. Karya sastra juga 
merupakan cerminan masyarakat pada zamannya. Melalui karya sastra, pengarang mengungkapkan problematika kehidupan yang pengarang sendiri ikut berada di dalamnya. Karya sastra menerima pengaruh dari masyarakat dan sekaligus mampu memberi pengaruh terhadap masyarakat. Bahkan seringkali masyarakat menentukan nilai karya sastra yang hidup di suatu zaman.

Mengaji sastra adalah hal yang menarik dan tidak pernah terhenti selagi karya sastra itu masih diciptakan. Hal ini disebabkan sastra memiliki hubungan yang cukup erat dengan kehidupan, khususnya pengarang dan pembacanya. Karya sastra merupakan karya kreatif yang diciptakan oleh manusia, di mana di dalam karya sastra, bahasa digunakan sebagai mediumnya. Karya sastra juga digunakan sebagai sarana hiburan bagi pembaca. Dengan membaca karya sastra, pembaca juga memperoleh kepuasan sendiri. Peneliti memfokuskan penelitian ini pada genre prosa yaitu novel. Novel adalah bentuk prosa baru yang di dalamnya terdapat cerita panjang mengenai kehidupan tokoh di dalamnya dan bersifat fiksi atau nonfiksi.

Novel sebagai salah satu karya fiksi memuat pesan dari pengarangnya. Pembaca harus memahami keutuhan dan keterkaitan antar unsur pembangun novel agar dapat memahami pesan yang disampaikan pengarang (Nurgiyantoro, 2010: 22). Sebuah karya sastra mengungkapkan nilai-nilai kehidupan untuk mendidik masyarakat yang membacanya. Nilai-nilai kehidupan yang tergambar dalam cerita dapat memengaruhi pola pikir masyarakat dalam kehidupan.

Salah satu novelis di Indonesia yang fenomenal dan telah merevolusi sastra Indonesia dengan karya-karya tebaiknya adalah Eka Kurniawan. Novel pertama Eka adalah Cantik Itu Luka berhasil mendapatkan penghargaan long list Khatulistiwa Literary Award 2003. Novel yang diterbitkan tahun 2002 ini telah diterbitkan dalam 30 bahasa dan memperoleh penghargaan bergengsi lainnya. Selain itu, beberapa karya lainnya telah diciptakan oleh Eka Kurniawan diantaranya: novel yang berjudul Lelaki Harimau (2004), novel Seperti Dendam, Rindu Harus Dibayar Tuntas (2014), novel $O$ (2016), cerpen Corat-coret di Toilet (2000), cerpen Gelak Sedih (2005), cerpen Cinta Tak Ada Mati (2005), cerpen Perempuan Patah Hati yang Kembali Menemukan Cinta Melalui Mimpi (2015), dan karya tulis nonfiksi yang berjudul Pramoedya Ananta Toer dan Sastra Realisme Sosialis (1999). Peneliti memilih novel Cantik Itu Luka sebagai objek penelitian karena terdapat beberapa pandangan tentang perempuan dalam tokohtokohnya yang dapat dikaitkan dengan peran Eka sebagai penulis laki-laki yang banyak mengangkat isu seputar perempuan dalam karya-karyanya. Dengan menggunakan cara kerja kritik sastra feminis, penelitian ini akan 
berfokus pada konstruksi kecantikan pada tokoh perempuan dalam novel Cantik Itu Luka karya Eka Kurniawan. Untuk menganalisis konstruksi kecantikan perempuan pada novel Cantik Itu Luka Karya Eka Kurniawan, diperlukan analisis tokoh dan penokohan, kritik sastra feminis, dan teori gender.

\section{Tokoh dan Penokohan}

Tokoh dan penokohan merupakan bagian penting dalam suatu cerita. Jika dalam cerita tidak terdapat tokoh dan penokohan, mustahil akan adanya cerita. Sebab, dalam suatu cerita pasti terdapat tokoh dan penokohan yang diceritakan.

Menurut Kosasih (2008: 61) Penokohan adalah cara pengarang dalam menggambarkan dan mengembangkan karakter tokoh-tokoh dalam cerita. Sedangkan menurut Aminuddin (2014: 79) pelaku yang mengemban peristiwa dalam cerita fiksi sehingga peristiwa tersebut mampu menjalin suatu cerita itu dengan tokoh. Para tokoh yang terdapat dalam suatu novel memiliki peran yang berbeda-beda. Tokoh inti atau tokoh utama, terdapat pula tokoh pembantu yang munculnya hanya sesaat sebagai pelengkap pendukung peran utama.

Adapun menurut Nurgiyantoro (2010:165) istilah tokoh mengacu pada orangnya, pelaku cerita. Tokoh adalah salah satu unsur yang penting dalam sebuah novel atau cerita rekaan, apabila sebuah prosa tanpa adanya tokoh tentu saja prosa tersebut tidak akan menarik dan terasa monoton. Menurut Abrams (dalam Nurgiyantoro, 2010:165) tokoh cerita merupakan orang-orang yang ditampilkan dalam suatu karya naratif atau drama oleh pembaca kualitas moral dan kecenderungan tertentu seperti yang diekpresikan dalam ucapan dan dilakukan dalam tindakan. Berdasarkan pengertian di atas dapat diartikan bahwa pengertian tokoh adalah individu yang mengalami peristiwa dalam cerita yang diberi watak oleh pengarang.

Penokohan dan perwatakan adalah penggambaran mengenai tokoh dalam cerita yang dilakukan oleh pengarang baik secara tersurat maupun tersirat dalam sebuah teks karya sastra. Penggambaran tokoh ini biasanya meliputi keadaan lahirnya maupun batin yang dapat berubah, pandangan hidup, sikap, penilaian sosial, keyakinannya, adat istiadat, dan sebagainya. Menurut Jones (dalam Nurgiyantoro, 2010: 165) penokohan adalah pelukisan gambaran yang jelas tentang seseorang yang ditampilkan dalam sebuah cerita.

Berdasarkan pendapat di atas, tokoh sebagai pelaku dalam cerita, sedangkan penokohan merupakan sifat atau karakter yang dibentuk oleh pengarang pada tokoh dalam cerita tersebut. Akan tetapi keduanya saling berhubungan satu sama lain. 


\section{Kritik Sastra Feminis}

Feminis merupakan suatu gerakan perempuan untuk menuntut keadilan gender, memperjuangkan emansipasi (persamaan hak kaum wanita dengan kaum pria) tanpa adanya diskriminasi. Menurut Ratna (2004: 226) feminis berasal dari kata femme yang berarti perempuan. Lebih lanjut Ratna (2004: 226) menjelaskan bahwa kemudian timbul gerakan feminis yang secara khusus menyediakan konsep dan teori dalam kaitannya dengan analisis kaum perempuan. Secara etimologi, feminis menurut Ratna (2004: 184) berarti perempuan (tunggal) yang berjuang untuk memperjuangkan hak-hak kaum perempuan (jamak), sebagai kelas sosial.

Adapun feminisme menurut Bhasin dan Khan (1995: 5) adalah sebuah kesadaran terhadap ketidakadilan bagi perempuan dalam berbagai sektor kehidupan.

Feminisme mengandung 3 konsep, yaitu:

1. Feminisme adalah sebuah keyakinan bahwa tidak ada perbedaan seks, yaitu menentang adanya posisi hirarki yang menyebabkan posisi superior dan inferior diantara jenis kelamin.

2. Feminisme adalah sebuah pengakuan bahwa dalam masyarakat telah terjadi konstruksi sosial budaya yang merugikan perempuan.

3. Feminisme menuntut perbedaan yang mencampuradukan seks dan gender sehingga perempuan dijadikan sebagai kelompok tersendiri dalam masyarakat.

Menurut Shelden (dalam Ratna 2004: 194-195) terdapat lima masalah yang muncul dalam teori feminis. Diantaranya sebagai berikut.

1. Masalah Biologis

Masalah biologis berkaitan dengan kodrat perempuan dan hakikat yang harus diterima secara alamiah.

2. Pengalaman

Masalah pengalaman dikaiatkan dengan ciri khas keberadaan perempuan sebagai akibat perbedaan biologis, seperti menstruasi, mengandung, dan melahirkan. Hal ini pada akhirnya menimbulkan perbedaan persepsi.

3. Wacana

Perempuan termarginalisasikan akibat dari wacana yang dikuasai oleh kaum laki-laki. Wacana menjadi perdebatan penting dalam teori feminis.

4. Ketaksadaran

Ketaksadaran berkaitan dengan teori psikoanalitik Lacan dan Kristeva.

5. Masalah Sosioekonomi

Dimensi sosioekonomi berkaitan dengan kondisi sosial, ekonomi, dan politik.

Tujuan awal feminisme adalah untuk menyetarakan antara kedudukan perempuan dengan kedudukan laki-laki. Feminisme memperjuangkan kemanusiaan kaum 
perempuan dan memperjuangkan perempuan sebagai manusia merdeka seutuhnya.

Menurut Sugihastuti dkk (2016: 18) feminis berhubungan dengan konsep kritik sastra feminis, yaitu studi sastra yang terfokuskan menganalisis terhadap perempuan. Dalam hal tersebut karya sastra melibatkan perempuan dalam pengkajiannya. Senada dengan Wiyatmi (2012: 1) kritik sastra merupakan salah satu kritik sastra yang memanfaatkan kerangka teori feminis dalam menginterpretasi dan memberikan evaluasi terhadap kerja sastra.

Berdasarkan definisi di atas, dapat dikatakan bahwa kritik sastra feminis adalah studi sastra yang mengarahkan fokus analisisnya pada perempuan. Selain itu, kritik sastra feminis menginginkan adanya keadilan dalam memandang eksistensi perempuan. Hal inilah yang tergambar dalam novel Cantik itu Luka, sehingga kritik sastra feminis peneliti anggap sebagai pendekatan yang relevan untuk digunakan dalam penelitian ini. Sementara itu, untuk menganalisis tentang persoalan gender dibutuhkan sebuah pendekatan khusus, salah satunya adalah teori gender yang akan dikemukakan pada bagian selanjutnya.

\section{Teori Gender}

Gender merupakan kontruksi sosial dalam suatu negara yang dipengaruhi oleh kondisi sosial, politik, budaya, ekonomi, agama maupun lingkungan etnis. Gender bukan jenis kelamin, melainkan sesuatu yang dilakukan, sesuatu yang ditampilkan. Menurut Fakih (2010: 8) gender merupakan sifat yang melekat pada kaum perempuan dan kaum laki-laki yang dikontruksi secara sosial maupun kultural. Contohnya, perempuan dikenal memiliki sifat lemah lembut dan emosional. Sifat tersebut dapat dipertukarkan. Konsep gender juga dapat diketahui dari peranan laki-laki dan perempuan. Peran bekerja tidak hanya dilakukan kaum laki-laki, tetapi juga dapat dilakukan kaum perempuan. Senada dengan pendapat Sugihastuti dkk (2016: 33) gender merupakan suatu sifat yang melekat pada kaum perempuan dan kaum laki-laki yang dikonstruksi secara sosial maupun kultural.

Berdasarkan pendapat di atas dapat diketahui bahwa gender bukanlah kodrat yang diberikah oleh Tuhan kepada manusia, melainkan perilaku yang dibentuk oleh manusia itu sendiri yang dipengaruhi oleh kondisi sosial, politik, budaya, ekonomi, agama maupun lingkungan etnis. Gender merupakan sifat atau perilaku laki-laki dan perempuan yang tidak didapatkan sejak lahir serta dibentuk secara sosial. Pembentukan ini menyebabkan terjadinya perbedaan gender berdasarkan jenis kelamin dan sifat, serta ciri dari laki-laki dan perempuan.

Perbedaan gender pada dasarnya tidak menjadi masalah selama tidak melahirkan ketidakadilan, namun pada kenyataannya 
gender ini melahirkan budaya patriarki serta menimbulkan ketidakadilan, khususnya bagi kaum perempuan. Ketidakadilan merupakan sistem dan struktur di mana baik kaum lakilaki ataupun kaum perempuan menjadi korban dari sistem tersebut. Ketidakadilan gender terwujudkan dalam berbagai bentuk ketidakadilan, yakni: marginalisasi atau proses pemikiran ekonomi, subordinasi atau anggapan tidak penting dalam keputusan politik, pembentukan stereotipe atau melaluo pelabelan negatif, kekerasan (violence), beban kerja lebih panjang dan banyak (burden), serta sosialisasi ideologi nilai peran gender (Fakih, 2013: 12). Terwujudnya ketidakadilan gender salah satunya yaitu stereotip gender. Stereotip secara umum merupakan pelabelan atau penandaan terhadap suatu kelompok tertentu (Fakih, 2013: 16).

Berdasarkan pendapat di atas dapat diketahui bahwa stereotip gender merupakan keyakinan yang diciptakan oleh masyarakat mengenai peran sosial dan keyakinan mengenai pembagian kelas berdasarkan jenis kelamin. Kenyataan di masyarakat stereotip gender menimbulkan diskriminasi pada kaum perempuan, sehingga kaum perempuan sangat dirugikan.

Adapun tujuan dari penelitian ini ada sebagai berikut.
1. Mendeskripsikan tokoh dan penokohan pada novel Cantik Itu Luka Karya Eka Kurniawan.

2. Mendeskripsikan gambaran persoalan perempuan pada konstruksi kecantikan dalam novel Cantik Itu Luka karya Eka Kurniawan.

\section{METODE PENELITIAN}

Metode yang digunakan dalam penelitian ini adalah metode kualitatif dengan cara deskriptif analisis yakni penelitian yang tidak hanya sebatas pada pengumpulan data, tetapi juga melakukan analisis dan interpretasi data tersebut, data dalam penelitian ini adalah teks novel. Penelitian ini menggunakan pendekatan deskriptif karena sumber data yang diteliti langsung berupa teks novel karya Eka Kurniawan dan peneliti ini adalah instrumen kunci untuk menganalisis data tersebut.

Metode penelitian deskriptif merupakan sebuah metode yang digunakan untuk mendeskripsikan, menginterpretasikan suatu fenomena dengan menggunakan prosedur ilmiah untuk menjawab permasalahannya secara aktual. Adapun tujuan metode penelitian deskriptif ini adalah untuk membantu pembaca mengetahui apa yang terjadi di lingkungan di bawah pengamatan, seperti apa pandangan partisipan yang berada di latar belakang penelitian, dan 
seperti apa peristiwa atau aktivitas yang terjadi di latar penelitian (Emzir, 2011: 174).

Adapun

langkah-langkah

penyelesaian masalah yang peneliti akan

lakukan dengan cara teknik kepustakaan, di antaranya sebagai berikut.

1. Membaca dan memahami novel

Peneliti membaca novel yang berjudul

Cantik Itu Luka karya Eka Kurniawan dan memahami struktur, dan representasi perempuan yang terdapat dalam novel tersebut.

\section{Mencatat data-data yang diperlukan}

Selanjutnya peneliti mencatat datadata yang terkait dalam novel tersebut sesuai dengan kepentingan dalam analisis.

3. Menguraikan data

Setelah peneliti melakukan pencatatan, selanjutnya peneliti menguraikan hasil data tersebut.

\section{HASIL DAN PEMBAHASAN}

Hasil penelitian ini terdiri 3 bagian, yaitu 1) tokoh dan penokohan, 2) Konstruksi kecantikan perempuan pada novel Cantik itu Luka, 3) ketidakadilan terhadap perempuan pada novel Cantik itu Luka. Di antaranya sebagai berikut.

\section{Tokoh dan Penokohan}

Tokoh dan penokohan merupakan bagian penting dalam suatu cerita. tokoh mengacu kepada orangnya atau pelaku cerita, sedangkan penokohan merupakan karakter tooh-tokoh dalam cerita. Dalam novel Cantik Itu Luka terdapat beberapa tokoh, namun peneliti membatasi pada tokoh Dewi Ayu, Alamanda, Adinda, Maya Dewi, dan Cantik. Berikut di bawah ini pemaparan hasil analisis terhadap tokoh-tokoh tersebut.

1) Dewi Ayu

Dewi Ayu merupakan tokoh utama dalam cerita sebagai ibu dari Alamanda, Adinda, Maya Dewi, dan Cantik yang memiliki paras cantik. hal tersebut dapat dilihat pada kutipan berikut.

"Ia duduk di sudut itu tampak acu tak acuh. Di bawah cahaya lampu, kulitnya sangat bersih, menandai warisan yang nyata orang-orang Belanda. Ia peranakan campuran, dengan mata yang agak kebiruan. Rambutnya hitam gelap, disanggul memanjang seperti sanggul perempuan-perempuan Prancis. Ia masih merokok, dengan sigaret yang diapit jari-jemari ramping panjang., kuku-kukunya dikutek merah darah. Dewi Ayu mengenakan gaun warna gading dengan tali mengikat pinggangnya yang ramping. Ia mendengar apa yang dikatakan lelaki itu pada Mama Kalong, lalu ia mendongak menoleh padanya. Sejenak mereka saling memandang dan Dewi Ayu tersenyum menggoda tanpa beranjak" (Kurniawan, 2020: 127).

Kutipan di atas menunjukkan bahwa penampilan Dewi Ayu merupakan hal pertama yang dilihat seseorang saat belum mengenali siapa dirinya. Tidak ada satupun lelaki yang tidak tertarik dan terpesona oleh 
kecantikan Indo-Belanda yang melekat pada tubuhnya. Belum lagi saat gerak-gerik tubuhnya, tatapan matanya yang penuh akan godaan, semua yang ada pada dirinya mampu membuat siapapun jatuh hati. Selain kecantikan yang dimilikinya, Dewi Ayu memiliki sifat yang cerdas berbeda dengan perempuan yang lainnya. Hal tersebut dapat dilihat pada kutipan sebagai berikut.

"Mereka dibuat kagum dengan kecerdaan alamiah nya namun di buat khawatir oleh kecantikannya, hingga beberapa biarawati mulai membujuknya untuk meneruskan karier sebagai biarawati dan mengambil sumpah kemiskinan, keheningan, dan kesucian. "Itu tak mungkin, " katanya "jika semua perempuan mengambil sumpah semacam itu, umat manusia akan punah seperti dinosaurus". Cara bicaranya yang mengejutkan adalah hal lain yang lebih mengkhawatirkan. Bagaimanapun, satu-satunya hal yang iya sukai dari agama hanyalah cerita-cerita fantastisnya, dan satu-satu nya yang ia sukai dari gereja hanyalah dentang lonceng Angelus yang bunyinya merdu terdengar, selebihnya ia tak begitu religius dan bahkan memperlihatkan tanda-tanda akan kehilangan imam" (Kurniawan, 2020: 41).

Kutipan di atas menunjukkan bahwa Dewi Ayu memiliki pemikiran emansipasi, menolak jadi biarawati karena menurutnya syarat-syarat yang berlaku sangat jauh dari kata kebebasan bagi perempuan untuk berekspresi dan mengaktualisasikan diri.
Dewi Ayu memiliki pola pikir yang berbeda menyikapi hal tersebut, ia mengedepankan kebebasan dan kemanusiaan dan tidak mencari posisi nyaman di bawah lindungan agama.

2) Alamanda

Alamanda merupakan anak pertama Dewi Ayu yang tidak diketahui siapa ayahnya, kecantikan yang ia miliki mampu menjadikannya sebagai daya tarik laki-laki yang melihatnya. Ia memiliki paras cantik ibunya. Kecantikan yang dimiliki Alamanda tidak ada bandingannya jika dibandingkan dengan perempuan mana pun. Hal tersebut dapat dilihat pada kutipan sebagai berikut.

"Tak seorang pun di kota ini, dan mungkin di seluruh alam semesta, lebih cantik darinya. Ia lebih cantik daripada Rengganis Sang Putri yang kawin dengan anjing, paling tidak menurutku. Ia lebih cantik dari Ratu Laut Kidul. Ia lebih cantik daripada Helena yang membuat perang Troya meletus. Ia lebih cantik dari Diah Pitaloka yang menyebabkan perang Majapahit dan Pajajaran. Ia lebih cantik daripada Juliet yang membuat Romeo nekat bunuh diri. Ia lebih cantik dari siapa pun. Seluruh tubuhnya seperti mengeluarkan cahaya, rambutnya lebih mengilau dari sepatu yang baru disemir, wajahnya begitu lembut seolah ia dibuat dari lilin, dan senyumnya seperti mengisap segala yang ada di sekitarnya" (Kurniawan, 2020: 173174).

Kutipan di atas menunjukkan bahwa Alamanda memiliki paras cantik menurut 
pandangan orang tidak ada bandingannya dengan siapapun. Hal tersebut menjadikan Alamanda disukai banyak lelaki. Paras cantiknya menjadikan kriteria ideal bagi lelaki yang melihatnya. Banyak lelaki di Halimunda yang jatuh hati padanya dan berusaha ingin dekat dengannya. Namun, Alamanda menjadikan kecantikan sebagai balas dendam kepada lelaki di kota Halimunda dengan menjadikannya patah hati. Hal tersebut dapat dilihat pada kutipan berikut.

"Di masa damai, Mama telah bikin lelaki-lelaki itu mengantri dan membayar untuk meniduri Mama, dan aku membuat banyak lelaki menangis karena patah hati" (Kurniawan, 2020: 200).

Kutipan di atas menunjukkan bahwa Alamanda kesal atas profesi yang dilakukan ibunya sebagai pelacur, ia membalaskan dendam dengan modal kecantikannya kepada para lelaki dengan membuat mereka patah hati. Berbeda dengan Dewi Ayu yang menjadikan kecantikannya sebagai sumber keuangan, Alamanda justru menjadikan kecantikan sebagai modal untuk mengecewakan para lelaki dengan tolakan.

3) Adinda

Adinda merupakan anak kedua Dewi Ayu, juga tidak diketahui siapa yang menjadi ayahnya. Ia memiliki paras cantik yang unik.
Hal tersebut dapat dilihat pada kutipan sebagai berikut.

“...Satu kecantikan yang unik, satu kecantikan para putri dan bidadari yang lembut dan mistis, tradisional, kuno, alami, dengan rambut yang dikepang dua, dengan mata yang terpejam itu dihiasi bulu mata lentik, dengan hidung mencuat ramping berhiaskan dua cuping bagai pahat demikian halus, dengan bibir yang merengut kecil, dengan pipi berisi, ..." (Kurniawan, 2020: 286-287).

Kutipan di atas menunjukkan bahwa Adinda memiliki kecantikan yang unik, sosok perempuan yang tradisional dengan tatanan rambutnya yang dikepang dua. Namun Adinda tidak menjadikan kecantikannya sebagai modal utama untuk sumber keuangan seperti yang dilakukan ibunya dan tidak menjadikan kecantikannya sebagai modal untuk menyakiti laki-laki seperti yang dilakukan kakaknya. Adinda merupakan perempuan yang setia, diam-diam Adinda menyukai kekasih Alamanda yaitu Kamerad Kliwon. Meskipun ia menyukainya, ia tidak menunjukkan bahwa dirinya menyukai Kamerad Kliwon kecuali kepada Alamanda. Adinda hanya mengancam akan membunuh Alamanda jika kakaknya tersebut menyakiti laki-laki yang dicintainya. Hal tersebut dapat dilihat pada kutipan sebagai berikut.

"Adinda bahkan bersumpah akan membunuhnya jika Alamanda berani 
menyakiti lelaki itu" (Kurniawan, 2020: 196).

Kutipan di atas menunjukkan bahwa Adinda setia kepada laki-laki yang ia cintai meskipun laki-laki tersebut merupakan kekasih kakaknya, ia rela melihat laki-laki yang dicintainya bersama kakaknya. Bahkan ia tidak ingin melihat laki-laki yang ia cintai tersakiti oleh cintanya Alamanda. Ia bersumpah akan membunuhnya jika laki-laki itu tersakiti.

4) Maya Dewi

Maya Dewi merupakan anak ketiga Dewi Ayu yang tidak diketahui siapa yang menjadi ayahnya. Maya Dewi juga memiliki kecantikan mirip dengan ibunya, Dewi Ayu. Hal tersebut dapat dilihat pada kutipan sebagai berikut.

“...Ia sungguh-sungguh demikian cantik, warisan kecantikan ibunya, dengan rambut yang mengembang di atas bantal, dengan buah dada yang mencuat terang-gelap di bawah temaram lampu, ...pinggulnya begitu indah dan kuat, ..." ( Kurniawan, 2020: 344).

Kutipan di atas menunjukkan bahwa Maya Dewi memiliki kecantikan yang diwarisi ibunya, Dewi Ayu. Kecantikan yang dimiliki Maya Dewi menjadikan kekhawatiran Dewi Ayu akan bernasib sama seperti dirinya dan kedua kakaknya Alamanda dan Adinda. Hal tersebutlah yang menjadikan
Dewi Ayu menjodohkan Maya Dewi dengan Maman Gendeng. Maman Gendeng merupakan laki-laki pilihan Dewi Ayu, meskipun yang dilakukan oleh Dewi Ayu merupakan hal yang aneh karena menjodohkan anaknya dengan laki-laki tua, namun menurut Dewi Ayu hal tersebut adalah pilihan yang terbaik untuk menyelamatkan masa depan Maya Dewi. Sifat penurutnya yang menjadikan pernikahan dirinya dengan Maman Gendeng terjadi. Meskipun demikian, Maya Dewi tidak terpaksa menerima perjodohan tersebut dan Maya Dewi mampu bersikap dewasa walaupun usianya masih terpaut muda dan ia juga mampu memposisikan dirinya sebagai istri. Ia rela berhenti sekolah demi mengurus suaminya tanpa diminta oleh siapa pun. Hal tersebut dapat dilihat pada kutipan berikut.

"Aku akan berhenti sekolah," kata Maya Dewi suatu ketika, mengejutkan Maman Gendeng” (Kurniawan, 2020: 343).

Kutipan di atas menunjukkan bahwa di usia belasan tahun, Maya Dewi memang sudah dinikahkan oleh ibunya dengan Maman Gendeng. Dari segi usia, keduanya memang terpaut jauh. Tapi Maya Dewi mampu memposisikan dirinya sebagai istri idaman. Meskipun ia masih sekolah, tapi ia mampu melayani suaminya seperti pasangan suami istri pada umumnya. Sampai-sampai ia ingin 
berhenti sekolah karena ia ingin mengurus rumah dan suaminya dengan lebih baik.

5) Cantik

Cantik merupakan anak bungsu dari

Dewi Ayu yang tidak diketahui siapa ayahnya. Cantik merupakan anak yang tidak diinginkan oleh Dewi Ayu yang terlahir dalam kondisi buruk rupa. Tak sesuai dengan namanya, wajah Cantik tidak ada hubungannya sama sekali dengan kecantikan. Hal tersebut menjadikan ia dijauhi orangorang dan sampai sekolah pun tidak ada yang menerimana. Meskipun ia tidak sekolah, ia memiliki kecerdasan dan keterampilan seperti manusia pada umumnya. Ia bisa menulis, membaca, dan bahkan ia pandai memasak. Meskipun demikian, menurut pandangan masyarakat Halimunda, Cantik adalah sosok manusia yang menakutkan. Hal tersebut dapat dilihat pada kutipan sebagai berikut.

"Ia gadis buruk rupa dengan lubang hidung menyerupai colokan listrik dan kulit hitam legam seperti jelaga. Ia gadis yang menakutkan, yang akan membuat orang mual dan muntahmuntah, membuat orang tak sadarkan diri dalam teror, membuat orang kencing di celana, membuat orang lari kesetanan, dan tidak membuat orang jatuh cinta" (Kurniawa, 2020: 490).

Kutipan di atas menunjukkan bahwa fisiknya Cantik bisa membuat orang ketakutan, mual dan muntah-muntah, membuat orang merasa dirinya dalam teror, membuat orang lari kesetanan karena ketakutan dan tidak membuat orang jatuh cinta. Namun ternyata kecantikan dan kejelekan seseorang hanyalah masalah dari sudut pandang bagaimana ia mendefinisikan kata cantik itu seperti apa. Hal tersebut digambarkan pada tokoh Krisan yang menurutnya tidak ada yang salah dengan perempuan buruk rupa. Hal tersebut dapat dilihat pada kutipan sebagai berikut.

"Selama bertahun-tahun, Krisan memikirkan terus ide itu, tentang memiliki kekasih yang buruk rupa. "Apa yang salah dengan perempuan buruk rupa?" katanya pada diri sendiri, "Mereka bisa dientot sebagaimana perempuan cantik." Dan ia teringat pada desas-desus tentang anak Dewi Ayu yang konon buruk rupa, mungkin yang paling menakutkan di muka bumi ini, dan meskipun ia tahu bahwa Dewi Ayu adalah neneknya, dan itu berarti si buruk rupa yang konon bernama $\mathrm{Si}$ Cantik itu bibinya, ia tak peduli. Ia pernah menyetubuhi sepupunya sendiri, apa salahnya menyetubuhi bibi sendiri” (Kurniawan, 2020: 504).

Kutipan di atas menunjukkan bahwa Cantik yang buruk rupa tersebut dapat menjadikan laki-laki menyukai dirinya. Lakilaki tersebut adalah Krisan dan tidak lain ia merupakan keponakannya. Bertahun-tahun Krisan memikirkan tentang memiliki kekasih yang buruk rupa dan pada akhirnya ia bertemu dengan Cantik. Menurut Krisan dalam kutipan di atas tidak ada yang salah dengan perempuan buruk rupa, mereka bisa 
disetubuhi sebagaimana perempuan cantik. Hal tersebut menjadikan Krisan ingin memiliki kekasih buruk rupa, sebab menurutnya bahwa cantik itu luka. Dapat dilihat pengakuannya pada kutipan berikut.

"Pengakuan keempat: Sebab cantik itu luka" (Kurniawan, 2020: 505).

Kutipan di atas menunjukkan bahwa Krisan mengakui bahwa cantik itu luka. Saat Cantik berhubungan dengan Krisan, tidak sedikit pun Krisan mempedulikan betapa menakutkan dan menjijikannya bentuk fisik Cantik. Ia bahagia bercumbu dengan Cantik dan bahkan ia memperoleh kebahagiaan yang nyaris tidak pernah ia peroleh selama masa hidupnya. Meskipun Cantik memiliki fisik yang buruk rupa, ia mampu menjadikan dirinya disukai oleh laki-laki layaknya seperti perempuan lain yang memiliki fisik lebih baik dari dirinya.

\section{Konstruksi Kecantikan Perempuan pada Novel Cantik itu Luka}

Pandangan cantik yang objektif dan universal tentunya berbeda-beda di setiap negara ataupun di setiap suku di Indonesia. Setiap suku memiliki pandangan cantik tersendiri. Namun dalam novel Cantik Itu Luka, cantik yang dipandang objektif dan universal tersebut mengacu kepada tokoh Dewi Ayu dan anak-anaknya Alamanda, Adinda, dan Maya Dewi. Mereka merupakan kiblat dari kecantikan perempuan di
Halimunda karena penilaian tokoh-tokoh lain. Hal tersebut dapat dilihat pada kutipan sebagai berikut.

“...kulitnya sangat bersih, menandai warisan yang nyata orang-orang Belanda. Ia peranakan campuran, dengan mata yang agak kebiruan. Rambutnya hitam gelap, disanggul memanjang seperti sanggul perempuan-perempuan Prancis. Ia masih merokok, dengan sigaret yang diapit jari-jemari ramping panjang., kuku-kukunya dikutek merah darah..." (Kurniawan, 2020: 127).

Kutipan di atas menunjukkan bahwa Dewi Ayu merupakan perempuan idaman semua laki-laki yang ada di Halimunda. Ia memiliki fisik yang nyaris sempurna dengan kulit sangat bersih, dengan mata agak kebiruan, dan memiliki rambut yang hitam gelap. Kecantikan yang ia punya memiliki kelas berbeda dari pelacur yang lainnya. Hampir semua laki-laki mengantri dan rela membayar berapapun demi bisa tidur bersamanya. Hal tersebut dapat dilihat pada kutipan berikut.

"Ia adalah pelacur paling favorit di kota itu. Hampir semua lelaki yang pernah ke tempat pelacuran, menyempatkan tidur paling tidak sekali bersamanya, tak peduli berapapun uang yang harus mereka bayarkan. Bukan karena mereka telah terobsesi lama untuk meniduri perempuan Belanda, tapi karena mereka tahu Dewi Ayu seorang pencinta yang baik" (Kurniawan, 2020 : 110). 
Kutipan di atas menunjukkan bahwa Dewi Ayu merupakan pelacur paling favorit. Kecantikan yang ia miliki menjadikan daya tarik laki-laki itu tinggi untuk sekedar menyalurkan nafsu birahinya. Selain memiliki fisik yag cantik, Dewi Ayu mampu bercinta dengan baik. Hal tersebutlah yang menjadikan laki-laki semakin terobsei untuk menidurinya dan bahkan Dewi Ayu menjadi objek dari kekuasaan budaya patriarki. Setiap laki-laki hanya memandang tubuhnya sebagai objek seksualitas. Hal tersebut dapat dilihat pada kutipan sebagai berikut.

"Semua kekuasaan beralih
kepadaku."Dan menambahkan hal
yang sangat penting baginya: "Tak
seorang pun boleh meniduri Dewi
Ayu di tempat pelacuran Mama
Kalong kecuali aku" (Kurniawan,
2020: 130).

Kutipan di atas menunjukkan bahwa Maman Gendeng memiliki kekuasaan sebagai preman yang ditakuti di Halimunda dan tak ada satupun orang yang bisa mengalahkannya. Dengan kekuasaan tersebut, ia tidak ingin ada laki-laki lain yang meniduri Dewi Ayu kecuali dirinya. Kecantikan yang dimiliki Dewi Ayu menjadi rebutan laki-laki yang ada di Halimunda. Tokoh Shodancho juga menggunakan kekuasaannya untuk mengendalikan Dewi Ayu. Shodancho merupakan tentara yang memenangkan semua pertarungan di medan perang. Ia memanfaatkan kekuasaan yang dimilikinya untuk meniduri Dewi Ayu Kekuasaan yang dimiliki Maman Gendeng dan Shodancho semakin diperkuat dari pertengkaran di antara keduanya. Hal tersebut dapat dilihat pada kutipan sebagai berikut.

"Dengar, Shodancho." Dan menambahkan dengan segera: "Tak seorang pun boleh dengan Dewi Ayu kecuali aku, dan kukatakan jika kau berani kembali ke tempat tidurnya, aku akan memporakporandakan tempat ini tanpa ampun" (Kurniawan, 2020: 138).

Kutipan di atas menunjukkan bahwa Maman Gendeng tidak terima atas perlakukan Shodancho meniduri Dewi Ayu. Kedua laki-laki yang memiliki kekuasaan tersebut saling memperebutkan Dewi Ayu hanya untuk mereka tiduri. Hal yang mereka lakukan tersebut wajar, karena Dewi Ayu bukan pelacur biasa.

\section{Memiliki kecantikan itu} menyenangkan dan anugerah bagi mereka yang mendapatkannya. Hampir semua perempuan ingin memiliki wajah yang cantik, sampai-sampai mereka harus membeli kosmetik, obat-obatan, dan bahkan sampai ada yang melakukan operasi plastik hanya demi mengubah wajahnya agar menjadi cantik. Namun pada novel Cantik Itu Luka, pengarang merepresentasikan bahwa cantik itu tidak selamanya menyenangkan dan anugerah. Cantik merupakan goresan luka 
bagi Dewi Ayu dan perempuan-perempuan lainnya yang memiliki paras cantik, karena pada akhirnya mereka dikuasai oleh tentara Jepang dan dipaksa menjadi pelacur. Selain kecantikan yang mereka miliki dan tubuh mereka yang dijadikan pemuas birahi, tokoh perempuan mengalami ketidakadilan dalam perlakukan yang mereka terima.

3. Ketidakadilan Terhadap Perempuan pada Novel Cantik Itu Luka

Masa penjajahan bukanlah masa yang mengenakan, terutama bagi perempuan yang dianggap lemah oleh kaum laki-laki. Keadilan sangatlah tidak mungkin dirasakan kaum perempuan, begitu pula yang dirasakan oleh Dewi Ayu. Meskipun yang dirasakan Dewi Ayu bentuk ketidakadilan, ia merupakan sosok yang pasrah dan tegar menerima keadaan. Sikap tersebut terlihat saat ia bernegosiasi kepada para penjajah dalam mempertahankan hidupnya. Akan tetapi hal tersebut tidak terhenti sampai akhir masa kolonial, ia justru hidup sebagai pelacur sampai akhir hayatnya. Dewi Ayu merupakan sosok perempuan yang cantik, namun kecantikannya justru membawa ia ke takdir yang menyedihkan. Sebagaimana dapat dilihat pada kutipan berikut.

"Berharaplah tentara kita dapat menangkap orang-orang Jepang" kata Dewi Ayu "kita akan ditukar seperti beras dan gula" (Kurniawan, 2020: 62).
Kutipan di atas menunjukkan ketegaran Dewi Ayu terhadap kekerasaan yang dilakukan oleh penjajah Jepang. Dewi Ayu beserta perempuan-perempuan lainnya mereka dijadikan sebagai alat untuk kegiatan politik. Tentara Jepang membawa semua perempuan dari anak-anak sampai perempuan tua. Mereka ditempatkan di tempat yang tidak layak untuk mereka jadikan sebagai tempat tidurnya. Hal tersebut dapat dilihat pada kutipan sebagai berikut.

"Malam pertama itu sungguhsungguuh merupakan horor yang mengerikan. Cahaya menghilang begitu cepat sebagaimana seharusnya di negeri tropis. Tak ada listrik di dalam tahanan, tapi hampir semua orang membawa lilin sehingga nyala kecil memenuhi ruangan dan dinding dipenuhi bayangan yang bergoyanggoyang membuat banyak anak kecil ketakutan. Mereka berbaring di lantai beralaskan matras, tampak menyedihkan, dan tak pernah sungguh-sungguh memperoleh tidur yang nyenyak. Tikus-tikus menyerang mereka di malam hari, dan nyamuk berdengung-dengung dari telinga yang satu ke telinga yang lain, dan codot beterbangan silang-menyilang. Hal ini diperparah oleh kunjungan mendadak tentara-tentara Jepang itu untuk melakukan pemeriksaan barang-barang bawaan. Mereka mencari orang yang masih menyembunyikan uang dan perhiasan" (Kurniawan, 2020: 67).

Kutipan di atas menunjukkan bahwa betapa menderitanya perempuan-perempuan yang ada dalam tahanan tersebut. Mereka 
tidak mendapatkan kenyamanan, yang mereka dapatkan hanyalah ketakukan. Lebih menyedihkannya lagi ketika salah satu teman Dewi Ayu yang bernama Ola meminta obat untuk kesembuhan ibunya, ia justru diminta berhubungan seks sebagai penembus obat. Tentara Jepang menjadikan hal tersebut sebagai kesempatan untuk memuaskan nasu birahinya. Dapat dilihat pada kutipan sebagai berikut.

“Apa kau bilang?" tanya Dewi Ayu. Ola menggeleng dengan lemah sambil melap air matanya dengan ujung lengan baju. "Tak mungkin," katanya pendek. "Komandan itu mau memberiku obat jika aku tidur dengannya" (Kurniawan, 2020: 71).

Kutipan di atas menunjukkan bahwa perempuan ditindas dan dimanfaatkan sekedar pemuas nafsu saja.

\section{SIMPULAN}

Berdasarkan hasil penelitian mengenai konstruksi perempuan dalam novel Cantik Itu Luka karya Eka Kurniawan, peneliti dapat memberikan simpulan sebagai berikut.

1. Tokoh-tokoh perempuan yang peneliti analisis di antaranya Dewi Ayu, Alamanda, Adinda, Maya Dewi, dan Cantik. Keempat tokoh tersebut memiliki bentuk fisik yang berbeda-beda. Tokoh yang memiliki fisik cantik di antaranya Dewi Ayu, Alamanda, Adinda, dan Maya
Dewi. Ketiga tokoh tersebut memiliki kecantikan dan daya tariknya masingmasing, mereka mampu mengalihkan pandangan laki-laki Halimunda. Setiap laki-laki yang memandangnya, ia langsung jatuh cinta pada pandangan pertama. Berbeda dengan tokoh Cantik, ia memiliki fisik yang buruk rupa. Namun meskipun demikian, ia mampu menjadikan dirinya disukai laki-laki.

Novel Cantik Itu Luka memaparkan tokoh-tokoh perempuan yang mengalami ketidakadilan pada masa kolonial. Kecantikan yang dimiliki tokoh perempuan dalam novel tersebut menjadikan dirinya malapetaka dan tubuhnya dijadikan sebagai objek pemuas birahi. Terutama tokoh Dewi Ayu sebagai pelacur favorit di Halimunda, ia merupakan perempuan yang memiliki fisik cantik dan juga pandai dalam bercinta. Hal tersebut menjadikan laki-laki dibuatnya untuk mengantri agar bisa meniduri Dewi Ayu.

\section{DAFTAR PUSTAKA}

Aminuddin. (2014). Pengantar Apresiasi Karya Sastra. Bandung: Sinar Baru Algensindo.

Bhasin, K. d. (1995). Persoalan Pokok Mengenai Feminisme dan Relevansinya. Jakarta: Gramedia Pustaka Utama.

Emzir. (2011). Metodologi Penelitisn Pendidikan. Jakarta: Rajawali Pers.

Fakultas Keguruan dan Ilmu Pendidikan 
Fakih, Mansour. (2010). Analisis Gender \& Transformasi Sosial. Yogyakarta: Pustaka Pelajar.

Kosasih, E. (2008). Apresiasi Sastra Indonesia. Jakarta: Nobel Edumedia.

Kurniawan, Eka. 2020. Cantik Itu Luka. Jakarta: PT Gramedia Pustaka Utama.

Nurgiyantoro, B. (2010). Teori Pengkajian Fiksi. Yogyakaarta: Gajah Mada University Press.

Ratna, Nyoman Kutha. (2004). Teori Metode, dan Teknik Penelitian Sastra. Yogyakarta: Pustaka Pelajar.

Wiyatmi. (2012). Kritik Sastra Feminis: Teori dan Aplikasinya dalam Sastra Indonesia. Yogyakarta: Ombak. 